\title{
Spodoptera frugiperda (J. E. Smith) (Lepidoptera: Noctuidae) in cotton: vertical distribution of egg masses, effects of adult density and plant age on oviposition behavior
}

\author{
Spodoptera frugiperda (J. E. Smith) (Lepidoptera: Noctuidae) em algodoeiro: \\ distribuição vertical de posturas, efeitos da densidade de adultos e da idade \\ das plantas sobre o comportamento de oviposição
}

\author{
Arlindo Leal Boiça Júnior ${ }^{1}$, Zeneide Ribeiro Campos²*, Alcebíades Ribeiro Campos², \\ Walter Veriano Valério Filho ${ }^{3}$, Ostenildo Ribeiro Campos ${ }^{4}$
}

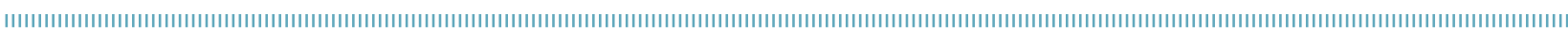

\begin{abstract}
The objective of this work was to determine the most suitable density of adults per plant, ideal plant age, and vertical distribution of eggs in different parts of the plant in a greenhouse investigation for future resistance studies and improvement of S. frugiperda management practices in cotton. The experiments of Spodotera frugiperda oviposition in relation to adult density, relationship between cotton plant age and Spodoptera frugiperda oviposition, Spodoptera frugiperda non-preference for oviposition on cotton varieties were conducted with plants of cotton variety BRS Ita 90. The experiments were conducted with plants of cotton variety BRS Ita 90. Non-preference (antixenosis) for oviposition was studied in FiberMax 966, FiberMax 977, DeltaOpal, DeltaPenta, Acala 90, Coodetec 408, Coodetec 409, Coodetec 410, BRS Cedro, BRS Ipê, BRS Aroeira, IPR 96, IPR 20, BRS Araçá, IAC 24 , and BRS Ita 90 varieties. We concluded that the fall armyworm S. frugiperda prefers to oviposit on plants with approximately 60 days of age, on the lower surface of leaves located in the upper third of the plant tests under greenhouse conditions. A density of at least three pairs of $S$. frugiperda adults per plant was sufficient to conduct non-preference-for-oviposition tests under greenhouse conditions. Coodetec 408, BRS Aroeira, BRS Araçá, BRS Ita 90 and DeltaPenta varieties showed non-preference-for-oviposition resistance to $S$. frugiperda. In regions with high infestations of S. frugiperda, it would be prudent for the cultivation the use of BRS Ita 90 cotton variety.
\end{abstract}

KEYWORDS: Gossypium hirsutum; host selection; plant resistance.

\begin{abstract}
RESUMO: O trabalho teve por objetivo determinar, em casa-de-vegetação, a densidade adequada de adultos, a idade ideal das plantas e a distribuição vertical de ovos nas diferentes partes da planta, visando à realização de estudos de resistência e à melhoria das práticas de manejo de Spodoptera frugiperda em algodoeiro. Os experimentos de oviposiçáo de $S$. frugiper$d a$ em relação à densidade de adultos, relação entre plantas de algodoeiro e oviposição de $S$. frugiperda e não preferência para oviposiçáo de $S$. frugiperda em variedades de algodoeiro foram realizados com plantas da variedade de algodoeiro BRS Ita 90. A não preferência (antixenose) para oviposição foi acompanhada nas variedades FiberMax 966, FiberMax 977, DeltaOpal, DeltaPenta, Acala 90, Coodetec 408, Coodetec 409, Coodetec 410, BRS Cedro, BRS Ipê, BRS Aroeira, IPR 96, IPR 20, BRS Araçá, IAC 24 e BRS Ita 90. Concluiu-se que $S$. frugiperda prefere ovipositar em plantas com cerca de 60 dias de idade, na superfície inferior das folhas situadas no terço superior dos testes de plantas sob condiçóes de estufa. Uma densidade de, pelo menos, três pares de adultos $S$. frugiperda por planta foi suficiente para realizar testes de não preferência para oviposição em casa de vegetação. As variedades Coodetec 408, BRS Aroeira, BRS Araçá, BRS Ita 90 e DeltaPenta apresentaram resistência do tipo não preferência para oviposição de $S$. frugiperda. Em regiōes com altas infestaçóes de $S$. frugiperda, seria prudente para o cultivo utilizar a variedade de algodáo BRS Ita 90.
\end{abstract}

PALAVRAS-CHAVE: Gossypium hirsutum; seleção hospedeira; resistência de plantas. \footnotetext{
Jaboticabal (SP), Brazil.

${ }^{2}$ Departamento de Fitossanidade, Engenharia Rural e Solos da Faculdade de Engenharia da UNESP - Ilha Solteira (SP), Brazil.

${ }^{3}$ Departamento de Matemática da Faculdade de Engenharia da UNESP - Ilha Solteira (SP), Brazil.

${ }^{4}$ Curso de Agronomia da Universidade Estadual de Mato Grosso (UNEMAT) - Alta Floresta (MT), Brazil.

*Corresponding author: zeneide@bio.feis.unesp.br

Received on: 04/10/2011. Accepted on: 26/08/2013
}

'Departamento de Fitossanidade da Faculdade de Ciências Agrárias e Veterinárias da Universidade Estadual Paulista “Júlio de Mesquita Filho” (UNESP) - 


\section{INTRODUCTION}

The pests are one of the major limiting factors for the exploitation of cotton in Brazil (BASTOS et al., 2010), including among these the fall armyworm, Spodoptera frugiperda (J. E. Smith) (Lepidoptera: Noctuidae). In recent years, this insect has grown in importance in the country's main cotton producing regions (Degrande, 1998; Fernandes et al., 2002; SANTOS et al., 2003).

The fall armyworm $S$. frugiperda is native to the tropical and subtropical regions of the Americas and it has widespread distribution in the American Continent (Luginbill, 1928; Moreira et al., 2003). In Brazil, the fall armyworm finds favorable climate and several hosts, which foster its occurrence across all regions year round (CRUZ, 1995; Soares; Vieira, 1998; Santos, 2001). Although the fall armyworm prefers to feed on grasses such as corn, millet, wheat, sorghum, rice, and sugarcane, it also attacks plants from other families of economic importance, including cotton (Ali et al., 1989; Cruz, 1995).

In annual agroecosystems consisting of soybean, corn, bean, and cotton, there is a continuous supply of food for polyphagous insects such as species of the genus Spodoptera (SANTOS, 2001). The existence of irrigated crops, especially in cerrado regions, extends the survival of insects through time, increasing the number of generations and facilitating the adaptation of insect pests. Under such situation, the moths migrate between crops consisting of related plant species, established during different seasons and among different botanical species (SANtos, 2001; Santos et al., 2003).

In cotton, $S$. frugiperda oviposit in most of the plants phenological stages, more often in the lower (ALI et al., 1989), middle (Ali et al., 1989; Miranda, 2006) and upper thirds of the plant (Miranda, 2006) and preferentially on the lower surface of the leaves (Pitre et al., 1983; Ali et al., 1989; SANTos, 1999; Ferreira, 2003; Miranda, 2006), in masses that may contain from 30 to 300 eggs (King; SAUnders, 1984; Freeman, 1999). Egg masses are held together and fixed to the substrate by a substance produced by the accessory glands of females and are covered with one or more layers of abdominal hairs (LuCCHINI, 1977; PATEL, 1981).

S. frugiperda chemical control in cotton is difficult because the egg masses are found on the lower surface of the leaves in the middle and lower thirds of the plant and also because first- and second-instar caterpillars remain near the area where eggs were laid, reducing the efficiency of sprays (Santos, 1998; Fernandes et al., 2002). The need to control $S$. frugiperda, among other pests, in cotton fields is a major cause of development and expansion of chemical control within the different regions of Brazil. Thus, a new model of agriculture that recommends changing the environment as little as possible has led researchers to study new tools aimed at improving the Integrated Management of $S$. frugiperda in cotton crop, particularly those used during the sampling procedures and other related resistance of cotton varieties pest, studied here.

Thus, the objective of this research was to determine the oviposition site preferred by $S$. frugiperda in different cotton plant parts, the most suitable adult density and the best plant age to conduct resistance tests in the greenhouse, as well as its non-preference (antixenosis) for oviposition on varieties of this crop.

\section{MATERIAL AND METHODS}

The studies reported in this paper were performed in the Entomology Laboratory of the Phytosanitary, Rural Engineering and Soils Department of the Engineering School (UNESP), Ilha Solteira, São Paulo State, in 2007, with geographic coordinates $20^{\circ} 25^{\prime} 58^{\prime \prime} S$ latitude and $51^{\circ} 20^{\prime} 33^{\prime}$ O longitude.

Evaluations for adult density, plant age and oviposition distribution were conducted on plants of cotton variety BRS Ita 90. Non-preference for oviposition was studied in varieties FiberMax 966, FiberMax 977, DeltaOpal, DeltaPenta, Acala 90, Coodetec 408, Coodetec 409, Coodetec 410, BRS Cedro, BRS Ipê, BRS Aroeira, IPR 96, IPR 20, BRS Araçá, IAC 24, and BRS Ita 90.

The insects used in the experiments came from a $S$. frugiperda stock rearing started with individuals provided by EMBRAPA/CNPMS, Sete Lagoas, Minas Gerais State. The insects were reared and kept in the laboratory on artificial diet (KASTEN-Junior et al., 1978), using a methodology prepared by PARRA (1986).

Cotton plants of different varieties were grown in pots $(20 \mathrm{~L})$ containing substrate consisting of a mixture of soil, sand, and compost at a 2:1:1 ratio. Seeding was accomplished using five seeds per pot, and a thinning operation was conducted ten days after germination, leaving one plant per pot. Fertilization was performed according to the recommendation by VAN RAIJ (1991) with daily irrigation as needed.

During the evaluation period, adults were fed a $10 \%$ honey solution supplied in a dental roll attached to the leaf petiole with a small hook and replaced daily.

\section{Spodoptera frugiperda oviposition in relation to adult density}

Four $S$. frugiperda adult densities were evaluated in a nonchoice experiment with ten replicates in a completely randomized design. Plants at 60 days of age were individually 
protected with a hood made of tulle fabric measuring $60 \mathrm{~cm}$ in diameter and $120 \mathrm{~cm}$ in height, tied at the base of the stem. Infestations were performed on the second day after mating (observed in the laboratory) at densities of 1, 2, 3, and 4 S. frugiperda pairs per plant. The number of egg masses per plant was counted 48 and $72 \mathrm{~h}$ after infestation. Tests for densities ranging from 1 to 4 pairs of adults/plant were determined on the basis of the behavior of $S$. frugiperda which, according LuginbiLl (1928), oviposit indiscriminately, and being polyphagous, the larva has a chance to find a plant of its own to feed. Thus, it is considered that, with this number of pairs of adults tested, the probability to determine the number of couples suitable for the study of non-preference for oviposition in cotton plants is higher.

\section{Relationship between cotton plant age and Spodoptera frugiperda oviposition}

Cotton plants in three different phenological phases: phase B (30 to 45 days) - emergence of the first bud; phase F (60 to 75 days) - emergence of the first flower and phase $\mathrm{C}$ (from 90 days) - from the opening of the first capsule, were evaluated in a free-choice experiment with ten replicates, in a random block design organized as a split-plot in time. Plants, one per pot, were placed in a greenhouse within an area enclosed by tulle fabric and then subjected to infestation.

\section{Vertical distribution of Spodoptera frugiperda egg masses in cotton plants}

In a non-choice test, 60-day-old plants (one per pot), selected in the previous experiment, were placed in the greenhouse; each plant was protected by a hood made of tulle fabric, measuring $60 \mathrm{~cm}$ in diameter by $120 \mathrm{~cm}$ in height, tied at the base of the stem. Four pairs of $\mathcal{S}$. frugiperda adults were released per plant on the second day after mating in the laboratory. Evaluations were made 48 and $72 \mathrm{~h}$ after infestation by counting the numbers of egg masses present in upper, middle and lower thirds of the plant. In this trial, a completely randomized design was adopted, with ten replicates.

\section{Spodoptera frugiperda non-preference for oviposition on cotton varieties}

In this experiment (the non-preference for oviposition of S. frugiperda in cotton varieties) FiberMax 966, FiberMax 977, DeltaOpal, DeltaPenta, Acala 90, Coodetec 408, Coodetec 409, Coodetec 410, BRS Cedro, BRS Ipê, BRS Aroeira, IPR 96, IPR 20, BRS Araçá, IAC 24, and BRS Ita 90 varieties were used in six replicates and randomized design. Plants with 60 days (age defined in the previous experiment), one per pot, were placed in a greenhouse, within an area covered with tulle fabric type and subjected to infestation. For each plant, four adult couples were released, two days after mating in the laboratory. The ratings, counting the number of egg masses per plant, were taken 48 and $72 \mathrm{~h}$ after infestation.

\section{Statistical analyses}

The data, previously transformed to $(x+1)^{1 / 2}$, were submitted to analysis of variance (ANOVA) and the means were compared by Tukey's test at 5\% probability. The SisVar v. 5.0 software (Ferreira, 2003) was employed to run the analyses and means comparison tests.

\section{RESULTS AND DISCUSSION}

The differences between mean numbers of egg masses per plant under varying $S$. frugiperda adult densities were significant (Table 1). At densities of one and two adult pairs per plant, 6.2 and 7.1 egg masses per plant were observed, respectively; however, these are statistically equal the two others. Higher means, 14.5 and 20.9 egg masses per plant, were found at densities of three and four pairs per plant, respectively, differing from the two lower densities. Three or more pairs of adults per plant can be considered an appropriate density to conduct $S$. frugiperda resistance tests with cotton varieties under greenhouse conditions.

These densities, three or four pairs, determined by counting the numbers of egg masses per plant, were higher than those cited by Ferreira (2003), who used two mated females per plant while conducting tests with varieties BRS Ita 90 and Coodetec 404.

Considering the various cotton plant ages, the highest mean number of egg masses/plant was found in 60-day-old plants (7.89 egg masses per plant), significantly differing from the means obtained with plants at other ages (Fig. 1). Thirtyand 45-day-old plants were less oviposited (1.33 and $2.22 \mathrm{egg}$ masses per plant, respectively) in relation to 75 - and 90-day-old plants (3.22 and 4.78 egg masses per plant). The mean numbers

Table 1. Number (mean \pm standard deviation) of Spodoptera frugiperda egg masses/cotton plant, BRS Ita 90 variety, according to adult density.

\begin{tabular}{lc} 
Number of pairs/plant & Egg masses \\
\hline 1 pair & $6.20 \pm 1.01 \mathrm{~b}$ \\
\hline 2 pairs & $7.10 \pm 1.34 \mathrm{~b}$ \\
\hline 3 pairs & $14.50 \pm 2.01 \mathrm{a}$ \\
\hline 4 pairs & $20.90 \pm 1.52 \mathrm{a}$ \\
\hline F & $18.12^{* *}$ \\
CV & (\%) 20.77 \\
DMS & 0.87
\end{tabular}

Means followed by the same letter are not different from one another by Tukey's test at $5 \%$ probability.

F: F-test; CV: Variation of coefficient and the percentage (\%) is together with CV; DMS: minimum significant difference.

**Significant at $1 \%$ probability. 
of $S$. frugiperda egg masses found in cotton plants, regardless of age, match those obtained by ALi et al. (1989), who concluded that $S$. frugiperda oviposit on all cotton plant phenological stages. Ferreira, (2003) studied the oviposition, dispersal, and feeding behavior of $S$. frugiperda caterpillars on cotton varieties BRS Ita 90 and Coodetec 404 and used (using) two mated females per plant at 65 days of age when the plants simultaneously had flower buds, flowers, and bolls. From the results obtained in that experiment, it could be generally concluded that $S$. frugiperda prefers to oviposit on plants at 60 days of age.

Significant differences for mean number of egg masses per plant part among the three plant thirds were only observed for leaves (Table 2). Then, $52.63 \%$ of the egg masses were located in the plants' upper third; $34.21 \%$ in the lower third; and $13.16 \%$ in the middle third. In conditions of greenhouse, the results are partly similar to those found by FerReira, (2003), who cited the upper third of cotton plants as the preferred region for $S$. frugiperda oviposition. In contrast, the results obtained here differ, in part, from those achieved by Ali et al. (1989), SANTOS (1999) and Miranda (2006), who found a higher number of S. frugiperda egg masses in the plants' middle and lower thirds, when the data were collected in the field.

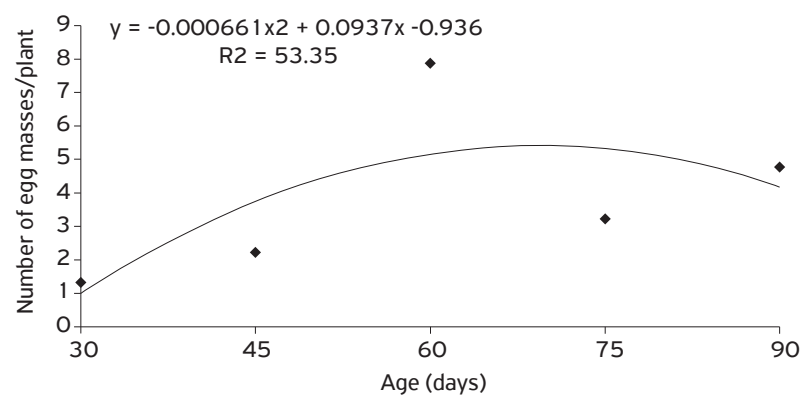

Figure 1. Relationship between cotton plant age and number of Spodoptera frugiperda egg masses in a free-choice test.
Regarding the distribution of eggs in different parts of the plant, no egg mass were observed on bracts, flower buds, flowers, and bolls during the evaluation period (Table 2), regardless of the position of those structures in the plant. The highest number of egg masses was found in the leaves (92.10\%), preferentially on the abaxial surface. Those results confirm the data found by Pitre et al. (1983), Ali et al.(1989), Ferreira, (2003) and Miranda (2006), who reported the abaxial surface of the leaves as the site preferred by $S$. frugiperda for oviposition.

Table 3. Numbers (mean \pm standard deviation) of Spodoptera frugiperda egg masses on different cotton varieties, $72 \mathrm{~h}$ after infestation, in a free-choice test.

\begin{tabular}{ll} 
Varieties & Egg masses \\
\hline IPR 96 & $0.67 \pm 0.33 \mathrm{ab}$ \\
\hline IPR 120 & $0.33 \pm 0.33 \mathrm{ab}$ \\
\hline FiberMax 966 & $0.67 \pm 0.67 \mathrm{ab}$ \\
\hline FiberMax 977 & $0.17 \pm 0.17 \mathrm{~b}$ \\
\hline Coodetec 408 & $0.02 \pm 0.00 \mathrm{~b}$ \\
\hline Coodetec 409 & $0.17 \pm 0.17 \mathrm{~b}$ \\
\hline Coodetec 410 & $2.17 \pm 0.70 \mathrm{a}$ \\
\hline BRS Ipê & $1.00 \pm 0.63 \mathrm{ab}$ \\
\hline BRS Aroeira & $0.00 \pm 0.00 \mathrm{~b}$ \\
\hline BRS Araçá & $0.00 \pm 0.00 \mathrm{~b}$ \\
\hline BRS Cedro & $0.50 \pm 0.22 \mathrm{ab}$ \\
\hline BRS Ita 90 & $0.00 \pm 0.00 \mathrm{~b}$ \\
\hline DeltaPenta & $0.00 \pm 0.00 \mathrm{~b}$ \\
\hline DeltaOpal & $0.17 \pm 0.17 \mathrm{~b}$ \\
\hline Acala 90 & $0.17 \pm 0.17 \mathrm{~b}$ \\
\hline IAC 24 & $1.17 \pm 0.75 \mathrm{ab}$ \\
\hline F & $2.38 * *$ \\
CV (\%) & 39.24 \\
DMS & 0.76 \\
\hline
\end{tabular}

Means followed by the same letter are not different from one another by Tukey's test at $5 \%$ probability.

F: F-test; CV: Variation of coefficient and the percentage (\%) is together with CV; DMS: minimum significant difference.

${ }^{* *}$ Significant at $1 \%$ probability.

Table 2. Numbers (mean \pm standard deviation) of Spodoptera frugiperda egg masses in different cotton plant parts, BRS Ita 90 variety.

\begin{tabular}{|c|c|c|c|}
\hline \multirow{2}{*}{ Plant parts } & \multicolumn{3}{|c|}{ Plant third } \\
\hline & Lower & Middle & Upper \\
\hline Leaves & $2.10 \pm 0.60 \mathrm{Ba}$ & $1.00 \pm 0.33 \mathrm{Ca}$ & $3.90 \pm 0.85 \mathrm{Aa}$ \\
\hline Bracts & $0.00 \pm 0.00 \mathrm{Ab}$ & $0.00 \pm 0.00 A b$ & $0.00 \pm 0.00 A b$ \\
\hline Bolls & $0.00 \pm 0.00 A b$ & $0.00 \pm 0.00 A b$ & $0.00 \pm 0.00 \mathrm{Ab}$ \\
\hline Petioles & $0.20 \pm 0.13 \mathrm{Ab}$ & $0.00 \pm 0.00 A b$ & $0.10 \pm 0.10 \mathrm{Ab}$ \\
\hline Flower buds & $0.00 \pm 0.00 A b$ & $0.00 \pm 0.00 A b$ & $0.00 \pm 0.00 A b$ \\
\hline Flowers & $0.00 \pm 0.00 A b$ & $0.00 \pm 0.00 A b$ & $0.00 \pm 0.00 A b$ \\
\hline Stems & $0.30 \pm 0.21 \mathrm{Ab}$ & $0.00 \pm 0.00 A b$ & $0.00 \pm 0.00 \mathrm{Ab}$ \\
\hline $\mathrm{F}$ (plant third) & & & $4.82^{* *}$ \\
\hline F (plant parts) & & & $46.06 * *$ \\
\hline CV (plant third) (\%) & & & 19.53 \\
\hline CV (plant parts) (\%) & & & 19.51 \\
\hline DMS & & & 0.09 \\
\hline
\end{tabular}

Upper case letters compare rows while lower case letters compare columns. Means followed by the same letter do not differ from one another by Tukey's test at $5 \%$ probability.

F: F-test; CV: Variation of coefficient and the percentage (\%) is together with CV; DMS: minimum significant difference.

**Significant at $1 \%$ probability. 
When comparing the mean number of eggs mass of S. frugiperda per plant, there is a preference for oviposition significantly as the higher range Coodetec 410 than in other materials (Table 3). Less oviposition was observed on FiberMax 977, Coodetec 409, Acala 90, DeltaOpal and Coodetec 408 varieties, while no oviposition was observed on plants of BRS Aroeira, BRS Araçá, BRS Ita 90, and Delta Penta varieties. Differences in oviposition behavior of $S$. frugiperda can be attributed to the morphological and chemical properties of plants of different cotton varieties studied.

The $S$. frugiperda oviposition preference results obtained on different cotton varieties (Table 3 ) are in agreement with those found by WIKLUND (1981), who stated that lepidopteran females show an oviposition preference hierarchy. THOMPson; Pellmyr (1991) observed that, in a free-choice situation, the female oviposit a higher number of eggs on the preferred host plant species, a smaller number on species with a lower degree of preference and so on. Within the concept of oviposition hierarchy, BRS Ita 90 variety behaves particularly as a secondary host, since it was oviposited by $S$. frugiperda when infested individually (Table 2), while, in the presence of other varieties, it was not oviposited at all (Table 3).

\section{CONCLUSIONS}

The fall armyworm $S$. frugiperda prefers to oviposit on plants with approximately 60 days of age, on the lower surface of leaves located in the upper third of the plant tests under greenhouse conditions.

A density of at least three pairs of adults $S$. frugiperda per plant was sufficient to conduct non-preference-for-oviposition tests under greenhouse conditions.

The Coodetec 408, BRS Aroeira, BRS Araçá, BRS Ita 90, and DeltaPenta varieties showed non-preference-foroviposition resistance to $S$. frugiperda.

In regions with high infestations of $S$. frugiperda, it is more suitable the cultivation of the BRS Ita 90 cotton variety.

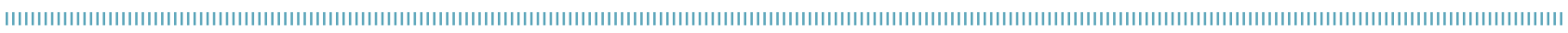

\section{REFERENCES}

ALI, A.; LUTTREL, R.G.; PITRE, H.N.; DAVIS, F.M. Distribution of fall armyworm (Lepidoptera: Noctuidae) egg masses on cotton. Environment Entomology, v.18, n.5, p.881-885, 1989.

BASTOS, E.M.; TORRES, J.B.; BUENO, A.F. Oviposicão, desenvolvimento e reprodução de Spodoptera frugiperda (J. E. Smith) (Lepidoptera: Noctuidae) em diferentes hospedeiros de importância econômica. Neotropical Entomology, v.39, n.6, p.996-1001, 2010.

CRUZ, I. A lagarta-do-cartucho na cultura do milho. Sete Lagoas: EMBRAPA/CNPMS, 1995.

DEGRANDE, P.E. Manejo integrado de pragas do algodoeiro. In: EMBRAPA, Centro de Pesquisas Agropecuárias do Oeste (Dourados, MS). Algodão: informações técnicas. Dourados: EMBRAPA-CPAO; Campina Grande: EMBRAPA-CNPA, 1998. p.154-191.

FERNANDES, M.G.; BUSOLI, A.C.; BARBOSA, J.C. Distribuição espacial de Spodoptera frugiperda (J. E. Smith, 1797) (Lepidoptera: Noctuidae) em algodoeiro. Revista Brasileira de Agrociência, v.8, n.3, p.203-211, 2002.

FERREIRA, D.F. SisVar - Sistema para análise de variância de dados balanceados. v. 5.0. Lavras: UFLA, 2003.

FERREIRA, M.A.F. Comportamento de oviposição, dispersão e alimentação de Spodoptera frugiperda (J. E. Smith, 1797), (Lepidoptera: Noctuidae) em algodoeiro herbáceo. 2003. $37 \mathrm{f}$. Dissertação (Mestrado em Agricultura Tropical) - Faculdade de Agronomia e Medicina Veterinária, Universidade Federal do Mato Grosso, Cuiabá, 2003.
FREEMAN, B.L. Cotton insect pests. ANR-409. 1999.

KASTEN-JUNIOR, P.; PRECETTI, A.A.C.M.; PARRA, J.R.P. Dados biológicos comparativos de Spodoptera frugiperda (J. E. Smith, 1797) em duas dietas artificiais e substrato natural. Revista de Agricultura, v.53, n.1-2, p.68-78, 1978.

KING, A.B.S.; SAUNDERS, J.L. The invertebrate pests of annual food crops in Central America. London: Overseas Development Administration, 1984.

LUCCHINI, F. Biologia de Spodoptera frugiperda (Smith ® Abbot, 1797) (Lepidoptera, Noctuidae). Níveis de prejuízos e avaliação toxicológica de inseticidas para o seu combate em milho. 1977. 114 f. Dissertação (Mestrado em Entomologia) - Universidade Federal do Paraná, Curitiba, 1977.

LUGINBILL, P.H. The fall armyworm. Technical Bulletin no 34. Washington: USDA, 1928.

MIRANDA, J.E. Distribuição vertical de lagartas de Spodoptera frugiperda no algodoeiro. Campina Grande: EMBRAPA/CNPA, 2006.

MOREIRA, M.D.; MIRANDA, J.E.; SILVA, C.A.D.; SOUZA JÚNIOR, J.D.A.; AZEVEDO, A.I.B. Aspectos biológicos e exigências térmicas da lagarta militar (Spodoptera sp.) (Lepidoptera: Noctuidae) em algodão. In: CONGRESSO BRASILEIRO DE ALGODÃO, 4., 2003, Goiânia, GO. Resumos. Goiânia: 2003. p.4. 
PARRA, J.R.P. Criação de insetos para estudos com patógenos. In: ALVES, S.B. (Coord.). Controle microbiano de insetos. São Paulo: Manole, 1986. p.348-373.

PATEL, P.N. Estudos de fatores bióticos de controle natural em populações de Spodoptera frugiperda (J. E. Smith, 1797) (Lepidoptera: Noctuidae). 1981. 98p. Dissertação (Mestrado em Ecologia) - Universidade Estadual de Campinas, Campinas, 1981.

PITRE, H.N.; MULROONEY, J.E.; HOGG, D.B. Fall armyworm (Lepidoptera: Noctuidae) oviposition: crop preferences and egg distribution on plants. Journal of Economic Entomology, v.76, p.463-466, 1983.

SANTOS, W.J. Problemas e soluções do manejo integrado de pragas do algodão. In: SEMINÁRIO ESTADUAL DO ALGODÃO, 4. 1998. Anais... Cuiabá: Fundação-MT. P. 3948, 1998.

SANTOS, W.J. Monitoramento e controle das pragas do algodoeiro. In: CIA, E.; FREIRE, E.C.; SANTOS, W.J. Cultura do algodoeiro. Piracicaba: Potafós, 1999. p.133-179.
SANTOS, W.J. Identificação, biologia, amostragem e controle das pragas do algodoeiro. In: EMBRAPA, Centro de Pesquisas Agropecuárias do Oeste. Algodão: tecnologia e produção. Dourados: EMBRAPA-CPAO, 2001.p. 181-226.

SANTOS, W.J.; SANTOS, K.B.; SANTOS, R.B. Ocorrência, descrição e hábitos de Spodoptera spp. em algodoeiro no Brasil. In: CONGRESSO BRASILEIRO DE ALGODÃO, 4., 2003, Goiânia, GO. Anais... Goiânia: EMBRAPA-CPAO, 2003. p.5.

SOARES, J.J.; VIEIRA, R.M. Spodoptera frugiperda ameaça $a$ cotonicultura brasileira. Campina Grande: EMBRAPA-CNPA, 1998.

THOMPSON, J.N.; PELLMYR, O. Evolution of oviposition behavior and host preference in Lepidoptera. Annual Reviews Entomology, v.36, p.65-89, 1991.

VAN RAIJ, B. Fertilidade do solo e adubação. São Paulo: Agronômica Ceres, 1991.

WIKLUND, C. Generalist vs. specialist oviposition behaviour in Papilio machaon (Lepidoptera) and functional aspects on the hierarchy of oviposition preferences. Oikos, v.36, p.63-70, 1981. 